\title{
Effect of Intercropping on Fruit Crops: A Review
}

\author{
P. Naveen Kumar \\ School of Agriculture, Lovely Professional University, Punjab, India \\ *Corresponding author
}

\begin{tabular}{l} 
K e y w o r d s \\
$\begin{array}{l}\text { Intercrop, Growth, } \\
\text { Soil health, Fruit } \\
\text { quality }\end{array}$ \\
Article Info \\
$\begin{array}{l}\text { Accepted: } \\
\text { 07 November } 2020 \\
\text { Available Online: } \\
10 \text { December } 2020\end{array}$ \\
\hline
\end{tabular}

\section{A B S T R A C T}

\section{Introduction}

Intercropping is the growing of two or more, usually dissimilar crops on the same piece of land. It is the complete utilization of the resources available at the farm. It not only provides a sustainable income to the farmer but also affects the soil health and nutrient availability. Intercrops, though of short duration, act as an insurance against the failure of the main crop. Intercrops add to the carbon pool of the soil thus enriching the soil with organic carbon. Research also shows that intercropping with gliricidia in maize resulted in $12 \%$ higher soil organic carbon (SOC) as compared to sole maize plantation (Beedy et al., 2010), although the effect of intercropping on carbon sequestration depends on cultural practice systems (Hairiah et al., 2000). Intercropping is a common practice in most of 
the countries. Selection of intercrops is the main aspect to consider while practicing intercropping. Wrong selection leads to the detrimental effects on yield of the main crop. If an error is made in selection of the intercrops, the same will compete with the main crop for water, light and nutrients (Ijaz et al., 2014). Citrus is a nutrition responsive crop and intercropping of citrus orchards with the legume crops helps for fixing the nitrogen in the soil biologically (Aziz et al., 2008: Srivastava et al., 2007). Further, in the organic citrus production, growing of intercrops suppresses the weeds and improves the fruit quality (Linares et al., 2008). Intercropping is also associated with increased nutrient use efficiency for $\mathrm{N}, \mathrm{P}$ and $\mathrm{K}$ while it had a positive effect on decreasing the soil erosion (Liu et al., 2015).

Intercropping is a complete technology which if adopted properly can-do wonders to the soil health and productivity of the fruit crops. Broadly, the various aspects of intercropping include detailed planning, timely planting, proper nutrient management, effective weed, insect pest and disease control and effective harvesting. Planning should involve selection of proper cultivars, timely planting, adequate water supply, plant species, plant populations, labour requirement, fertilizer requirements, profit analysis and pest and disease control (Prabhakar et al., 1983; Reddy and Willey, 1981). Based on the pattern of planting, intercropping is classified in to four groups (Vandermeer, 1992; Ofori and Stern, 1987).

Row-intercropping; The growing of two or more crops simultaneously where one crop is grown in regular rows and the other crops are also grown in the row with the first crop.

Mixed-intercropping; the growing of two or more crops simultaneously with no proper row management.
Strip-intercropping; the growing of two or more crops at the same time in different strips widely to permit the independent cultivation but narrow enough for the crops to interact ergonomically.

Relay-intercropping; the growing of two or more crops simultaneously in such a manner that the second crop is planted at the reproductive stage of the first crop but before it is ready to harvest.

\section{Advantages of intercropping}

Inter-cropping if done properly has many advantages such as

\section{Higher production}

Intercropping has been reported to be a remunerative option as compared to solo cropping (Caballero and Goicoechea, 1995). Martyn and Snaydan (1982) in their study reported that size of grain and dry matter accumulation in bean and barley was more when compared to monocropping. Relying more on intercropping resulted in higher growth rate, reduction of weeds, insect pest and transmitting diseases and more effective use of inputs due to differences in resource consumption (Eskandri, 2012b; Eskandari et al., 2009b; Watiki et al., 1993; Willey, 1990). This intercropping is very helpful for small scale farmers of very short season (Alteire 1985)

\section{Greater use of environmental resources}

Advantages of intercropping with the monocropping are the higher production that is due to the competition between the intercrops for environmental resources (Mahapatra, 2011; Valdez and Fransen, 1986). If there is any difference in the components lead to the greater utilization of all resources thus the production is also higher 
when compared to monocropping. (Jensen 1996). Wahua (1983) found that the intercropped maize and cowpea has the highest utilization of environmental resources when compared to the monocropping.

\section{Reduction of pests, disease and weeds damage}

The strategies involved in the pest reduction are divided into three groups 1) Delmiter crop hypothesis; the second species breakdown the ability of pest to attack its host. 2) Trap crop hypothesis; the second species attracted towards the main pest is attacked and it is normally used as pathogenic pests. 3) Natural enemies hypothesis; In intercropping predators and preys are attracted to crops, so the preys are parasitized (Danso et al., 1987).

More species diversity in agricultural ecosystems limit the spread of pathogens. Intercropping systems increase the diversity in ecosystem thus the increase in diversity reduces the pest and disease incidence (Anil et.al 1998).

Improve soil fertility and increase in nitrogen

Intercropping not only results in enhanced income through a diversified output but also improves soil fertility. Rhizobium bacteria fix the nitrogen biologically and it is symbiotically associated to leguminaceae family. As it fixes the atmospheric nitrogen into available nitrogen for plants uptake. So, it fixes the soil fertility by adding nitrogen to the soil.

Reports also indicating that nitrogen are increased in non-legume crops by intercropping with the legume crops. (Eskandari et al., 2009; Anil et al., 1998; Fujita et al., 1992).
Impact of intercropping on growth parameters

Guava intercropped with four seasonal vegetable crops (Arvi, bunda, suran and turmeric) and the data were collected before intercropping and after harvest. The results were showed significant affect on the growth parameters, average height ranged from 5.59 to $5.98 \mathrm{~m}$. Turmeric showed the maximum height and spread $5.96 \mathrm{~m}$ and $7.45 \mathrm{~m}$ as the rest of crops also showed the increase in growth parameters and there is no effect of vegetable crops in guava as compared to the sole cropping with control treatment. Better growth of the trees might be related with the better soil moisture conservation and nutrient status (Singh et al., 2016) and the better floor management (Singh and Sharma 2016). Gosh and Chand (1984) works also confirmed that growing of these short duration crops does not show any significant effect on perennial fruit crops

\section{Impact on flowering and fruiting}

Intercropping affects the overall performance of the plants. However this may or may not depend upon the season in which the cropping is done (Singh et al. 2016). When evaluation of guava fruit crops was done for rainy season and winter season crop using the intercropping, it was observed that average branches per tree ranged from 50.27-54.71, the average number of flowers per shoot ranged from 14.17 to 17.56 in rainy season which was comparable to the winter season performance of the guava plant. This showed that there was no significant variation with the intercropping among different seasons for the same crop. The maximum number of flowers was developed with the intercrop arvi 17.83 in rainy season and 7.12 in winter season. The average fruits per shoot ranged from 10 to 12 in rainy season and 3.97 to 5.33 in winter. However, the greatest number of fruits per 
shoot12.67 was with the sole crop followed by 11.93 in bunda showed there is no significant difference exhibited. In rainy season guava fruits have shown high range of fruit drop in sole crop $27 \%$ and $33 \%$ in bunda. Lower rate of fruit drop was recorded in winter guava crop with intercropped turmeric $20.67 \%$ and $27.21 \%$ in bunda. The number of flowers per shoot and fruit setting percentage in guava trees were higher with intercropped trees as compared to sole cropping and clearly indicating there is no adverse effect of vegetable crops in fruiting and flowering of guava. The flowering and fruiting percentage was higher in rainy season that was due to accumulation of nutrients while harvesting the trees in this season. The most set of flowering and fruiting percentage in guava might be the balanced nutrient in tissues which had ensured better utilization of the photosynthetic materials (Singh et al., 2016). Maji and das (2018) reported that intercropping improved the flowering and fruiting without affecting their own potential for production and also confirmed that vegetable crops improved fruiting and reduced fruit drop. From this evident it is clear that there is no adverse effect of vegetable crops intercropped with guava and also it enhanced the fruiting and flowering without affecting the intercrop potentiality and reduced the fruit drop percentage.

\section{Intercropping on yield and fruit quality}

Different systems have been investigated that can increase the yield to be taken from agriculture area in order to increase the crop production decreasing with the decrease of the agricultural areas available in the worldwide. One of these systems is intercropping. Intercropping is one of the most effective methods in agricultural production with a long history. It is known as the achievement of a high and stable production that not only raises complementary products in the area but also reduces the harmful effects of diseases and pests, prevents pollution and results in effective use of resources (Tirasci et al., 2017).

Various treatments of intercrops are given in the young Kinnow orchards and observed that there is a substantial increase in the yield and fruit quality as compared to the nonintercropped trees. This is due to the complementary utilization of all-natural resources and the efficient use of all inputs in the system (Panda et al., 2003). Among the growth parameters tree height and canopy spread is more in the intercropped trees as compared to the control. The maximum plant height was observed with the (guar + wheat) treatments and (moong + fenugreek) showed the positive response with high values was recorded. Singh et.al (2016) reported that the guava trees intercropped with the tuber crops showed the increased rate in plant height and spread, this was due to the better orchard floor management. In the economical perspective also, intercrops have showed the high gross income from each treatment compared to controlled. Intercropping with the legume crops showed the substantial increase in nitrogen and also the physical and chemical properties of soil that helps for improving the vegetative growth (Nath et al., 2008) in mango. Intercropping system attributes the utilization of environmental factors like soil moisture and solar radiation due to complementary utilization of the component crops, advantage for average fruit weight and fruit yield. The production of fruits per tree was maximum in the intercropped trees and minimum in non-intercropped. This was mainly by the leguminous crops increases nitrogen as a source of additional nitrogen to the soil from the findings of Gosh (2001) in guava trees fruits per tree was more. The TSS content from the fruit crops is maximum with the intercrops and the highest content with 
(Guar + wheat) treatment, similar results in terms of the fruit quality was reported in mango (Swain, 2016). Intercrops also helps main crops for creating the micro climate resulted more fruits per tree and fruit yield. Sahoo (2016) reported that average fruits from mango tree were more when compared to the sole cropping. Selection of crops should be specific as wrong choice and lack of knowledge leads to decrease in the fruit quality and yield. The more suitable crops are selected as complementary source between them such as legume crops for citrus. The results from the intercropping with (guar + wheat) reflected as better performance with good fruit quality, increase in plant height, plant spread, TSS content and gross income.

\section{Impact on physical characters}

Impact of intercropping on quality of guava fruits was evaluated using different intercrops like turmeric, arvi, suran and bunda. The physical parameters like fruit size, fruit weight and specific gravity of guava fruits were recorded (Singh et al. 2016). Intercropping with turmeric recorded maximum fruit length followed by intercropping with arvi in rainy season but in winter season, maximum fruit length was observed by intercropping with arvi followed by intercropping with suran. However, the diameter of the guava fruit was maximum when cultivated without any intercrop. There was no significant effect was observed on the fruit length and diameter intercropped with vegetable crop. Similarly, fruit weight was more when the intercropping was followed with suran followed by bunda and arvi in rainy season. During winter season, arvi intercropping performed better than other intercrops in guava. The specific gravity of fruits was not much influenced with the intercropping however, maximum specific gravity was observed with the intercrop suran both during rainy season and winter season.
The data from these physical factors revealed there was no much difference in the quality of fruits was observed due to intercropping. The aspects like average weight, fruit size, volume and specific gravity was observed more in winter season crop than rainy season guava. This was due to the availability of moisture, availability of nutrients and greater utilization of solar energy by terminal part of guava that lead for the better photosynthetic activity by Singh et al., (2014).

\section{Impact on chemical composition}

The average TSS content ranged from (8.45$9.02 \%)$ in rainy and $(9.40-9.68 \%)$ in winter season, highest TSS content was recorded with intercropped suran (9.03-9.68\%) followed by bunda (9.0-9.59\%) in rainy and winter seasons (Singh et al., 2016). The vitamin-C content was found to be more in winter than rainy season guava fruits, showed there is no much significant difference when intercropped. The greater amount of vit- $\mathrm{C}$ was recorded with the intercrop arvi followed by suran in rainy season and in winter season suran followed by arvi. The acidity content in fruits was ranged from $0.42-0.58 \%$ in rainy and $0.37-0.47 \%$ in winter season. However, the maximum content was observed in intercropped suran followed by bunda, respectively. The maximum content of nonreducing sugars observed in intercropped suran followed by bunda in rainy and winter seasons. The total sugars were not influenced much by the intercropped vegetables whereas, the highest percentage was found with the intercropped fruits suran and in bunda in guava fruits during winter and rainy seasons. The chemical composition of guava fruits had not been affected by the growth of intercrops and there was slight increase in the quality of fruit crops which might be due to the additional uptake of nutrients by fruit crop and less uptake of nutrients by intercrops. The growth of these intercrops does not have any 
effect on quality of fruits because of the restricted growth and less uptake of nutrients by Swain (2016).

All the growth characteristics, fruit quality flowering, fruit drop and the chemical characters of the fruits showed that there is no effect of these vegetable intercrops on the guava fruit in rainy and winter seasons. There was an improvement in the quality of the fruits was observed when intercropped with suran followed by bunda and arvi. These crops also suggested for reducing fruit drop and improving fruit quality, flowering and fruiting in the guava fruits.

\section{Impact on soil health and productivity}

Guava trees are intercropped with 8 crops (mano ginger, ragi, turmeric, niger, tomato, cowpea, paddy and French bean) and one control on red lateritic soil in sub-humid and sub-tropic climate to check the physiochemical properties of soil. Bulk density, electric conductivity, water holding capacity, soil moisture, organic carbon, soil $\mathrm{pH}$ and available NPK were determined.

The data from bulk density showed that there was improvement in the bulk density of soil intercropped with the cowpea1.28 $\mathrm{g} \mathrm{cc}^{-1}$ and French bean $1.29 \mathrm{~g} \mathrm{cc}^{-1}$ within $0-15 \mathrm{~cm}$ of soil and $1.31 \mathrm{~g} \mathrm{cc}^{-1}$ and $1.31 \mathrm{~g} \mathrm{cc}^{-1}$ as against 1.36 $\mathrm{g} \mathrm{cc}^{-1}$ and $1.37 \mathrm{~g} \mathrm{cc}^{-1}$ to the sole crop. The improvement in bulk density of soil also helps for increasing the soil organic matter by the accumulation of biomass from intercrops (Maheshwarappa et al., 1998).

The electrical conductivity of orchard of soil was increased with intercrop cowpea and Frenchbean within $15-30 \mathrm{~cm}$ of soil. The changes in physical, chemical and biological environment and increase in the soil organic matter attributes for increasing microbial activities in soil which might have improved the soil electrical conductivity (Maheshwarappa et al., 1998; Manna and Singh, 2001).

The nutrient availability to the plants and promoting the root activities are mainly influenced by the water upholding capacity of soil. The study carried out in two depths of soil and the results indicating that increasing water holding capacity was with the intercropping systems. The cowpea has the increased water holding capacity of soil than the other treatments with $34.5 \%$ and $30.1 \%$ against the control $28.0 \%$ and $26.1 \%$ within the $0-15$ and $15-30 \mathrm{cms}$ depth of soil. The recycling and addition of biomass under the intercropping systems helps for the improvement of organic carbon content, soil aeration and better soil structure so, it improves all the properties of soil which responsible for increasing improved water hold capacity to the soil (Maheshwarappa, 1998). The continuous intercropping reduces bulk density of soil by increasing water holding capacity of soil and reduces the pore space percentage (Gupta, 1983). Intercrops incorporate the crop residues to soil which helps for reducing evaporation loss due to the improved soil structure by the attribute higher soil moisture retention capacity (Kumar and Pandey, 2004).

The influence of intercrops on soil $\mathrm{pH}$ was studied at two depths of soil. The soil $\mathrm{pH}$ recorded within 0-15 and $15-30 \mathrm{~cm}$ was improved by the adoption of intercropping systems. Among the intercrop systems cowpea and French bean has resulted in increased $\mathrm{pH}$ at $0-15 \mathrm{cms}$ and cowpea and French bean under $15-30 \mathrm{cms}$ against the sole crop. Guava tree having maximum feeder roots at a depth of $30 \mathrm{~cm}$ of soil, so improvement in $\mathrm{pH}$ could be a better result for adaptation (Purseglove, 1974). The $\mathrm{pH}$ increase towards the neutral level is a desired factor for the soil improvement. Intercrops 
increased the process of nitrification and addition of biomass which might have influenced the ion exchange capacity to the soil so, that resulted in increased soil $\mathrm{pH}$ to the in between favorable change.

On-farm experiment was conducted in the village Badarpur said of Faridabad district in Haryana to assess the various intercrop combination in the lemon orchard during 2011 to 2014. The lemon variety Baramasi (Citrus limon) was planted in the area of 2,000 sq. m. in the year 2011. During rabi 2011 to rabi 2013-14, different crops like winter vegetables (cabbage and cauliflower), summer crops as muskmelon and fodder maize and kharif crops of maize (cob and fodder) and fodder sorghum were grown as intercrop in the orchard. The comparison was made in terms of net return from the system, crop productivity index and land equivalent ratio. Results showed that the best intercropping system was lemon + fodder maize - muskmelon - cauliflower. There was enhancement in land utilization, cropping intensity and farmers' income (Dubey et al., 2018)

\section{Impact on soil fertility status}

Significant improvement in fertility status of soil was observed under the intercrop-based systems in guava orchard. The results indicated that there was maximum improvement in the organic carbon content of soil with the intercropping system under cowpea with $0.72 \%$ and $0.65 \%$ within the depths of $0-15$ and $15-30 \mathrm{cms}$, comparing with the results of French bean. Intercrops increased the organic carbon content of soil by adding the decomposed biomass from legume crops. Intercropped systems of fruit based have increased soil organic carbon content with increasing the biological fertility by improving all the properties of soil by (Korwar et al., 2006 and Laik et al., 2009).
Intercropping with cowpea and French bean has increased the available nitrogen content in soil due to the maximum recycling of biolitters in the interspaces with greater content of nitrogen when compared to the other treatments (Manna and Singh, 2001 and Das et al., 2011). The increase in available nitrogen content with intercrops due to the fixation of atmospheric nitrogen by increasing the enzyme activity and microbial function by the leguminous crops on the rhizosphere.

The study revealed that phosphorous in the orchard soil had increased significantly by intercropping. The increased content of phosphorous in the soil might due to increase in the total micro-flora population with the intercrops, particularly the phosphorous solubilizers in the rhizosphere of plant by the findings of Verghese et al., (1978). The maximum available potassium was found in soil with the intercropped cowpea. This was due to increase in humus content of soil after the decomposition of biomass of the intercrops that enhanced the total population of beneficial microbes in the orchard soil by Swain and Patro (2007).

\section{Impact on leaf nutrients}

The intercropping with cowpea increased the NPK content in guava leaf as against the sole crop. The increase in the leaf $\mathrm{N}, \mathrm{P}$ and $\mathrm{K}$ was due to the increase in the availability of nutrients in the soil by the attributed huge amount of biomass by intercrop. It was also found that leaf NPK was higher with the leguminous intercrops and lower in nonintercrop. The incorporation of biomass by intercrops helped for improving the biological, chemical and physical status of soil which may have helped for better uptake of soil nutrients by the findings of Maheshwarappa et al., (1998) and Ghosh and Pal (2010). 
These intercrops do not have any adverse effect on soil health, productivity and soil fertility it is also recommended for improving the physio-chemical and biological environment of soil. Among these crops. cowpea has maximum affect on the plant that increased the physio-chemical properties of soil, improved the soil fertility status and also increased the leaf NPK status.

From this study it is concluded that intercropping does not have any adverse effect on the fruit crops. Intercrops has helped for reducing the fruit drop improving the yield, fruit quality, growth parameters, soil fertility, soil health and leaf NPK status. The leguminous crops have more intensity on the soil properties for improving the biological environment. Intercrops also improved the chemical composition of fruit which was desirable quality from consumers. It is recommended to grow intercrops in fruit orchards for better quality of fruits, improving physio-chemical properties of soil and also for complete utilization of all input resources. However, the selection of suitable crop and skillful knowledge is required for the cultivation of intercrops for reducing effect on main crop and better economic feasibility.

\section{References}

Altieri, M.A., 1995. Agroecology: the science of sustainable agriculture, second edition. Publisher: Westview Press.

Anil, L., J. Park, R.H. Phipps and F.A. Miller, 1998. Temperate intercropping of cereals for forage: review ofpotential for growth and utilization with particular reference to the UK. Grass and Forage Science, 53: 301-317.

Aziz, R.A.A., S.E. Salem and L. Al-Bitar (2008). Effect of intercropping cover crops on citrus orchards growth and fruiting under Toshka conditions. $J$. Agric. Vet. Sci., 1:101-110.
Beedy, T. L., Snap S. S., Akkinnifesi, F. K., Sileshi, G. W. (2010). Impact of Gliricidia sepum intercropping on soil organic matter fractions in a maize based cropping system. Agriculture Ecosystems and Environment. 138: 139-146.doi.

Caballero, R. and E.L. Goicoechea, 1995. Forage yield quality of common vetch and oat sown varying seeding ratios and seeding rates of vetch. Field Crops Research, 41: 135-140.

Danso, S.K., G. Hardarson and M. Fried, 1987. Nitrogen fixation in faba beans as affected by plant population density in sole or intercropped systems with barley. Soil Biology and Biochemistry, 19: 411-415.

Das, D. K., O. P. Chaturvedi, R. K. Jha, and Rajeev Kumar. 2011. Yield, soil health and Eco- nomics of aonla (Emblica officinalis Gaertn.)- based agrihorticultural systems ineastern India. Current Science 101 (6): 786-790.

Dinesh Kumar, and V. Pandey. 2004. A short note on vegetative growth of aonla as influenced by intercrops under rainfed conditions of Agra. Orissa Journal of Horticulture 32 (2):109 - 111.

Eskandari, H., 2012b. Intercropping of maize (Zea mays) with cowpea (Vigna sinensis) and mungbean (Vigna radiata): effect of complementarity of intercrop components on resource consumption, dry matter production and legumes forage quality. Journal of Basic and Applied Scientific Research, 2: 355-360.

Eskandari, H., A. Ghanbari and A. Javanmard, 2009a. Intercropping of cereals and legumes for forage production. Notulae Scientia Biologicae, 1: 07-13.

Eskandari, H., A. Ghanbari-Bonjar, M. Galavai and M. Salari, 2009b. Forage quality of cow pea (Vigna sinensis) 
intercropped with corn (Zea mays) as affected by nutrient uptake and lightinter- ception. Notulae Botanicae Horti Agrobotanici Cluj-Napoca, 37: 171-174.

Fujita, K., K.G. Ofosu and S. Ogata, 1992. Biological nitrogen fixation in mixed legume-cereal cropping system.Plant and Soil, 144: 155-175.

Ghosh SP and Chand S, Nutrient status of peach leaf affected by intercrops, Indian journal of agricultural sciences, $54,1984,450-451$.

Ghosh, S. N. (2001). Intercropping in guava orchard in watershed area. Hort. J., 14: 36-40.

Ghosh, S. N., and P. P. Pal. 2010. Effect of inter cropping on plant and soil of mosambi sweet orange orchard under rainfed conditions. Indian Journal of Horticulture 67(2): 185-190.

Gill, M.S. et al. (2018). Impact of intercropping on yield, fruit quality and economics of young Kinnow mandarin plants. Journal of Applied and Natural Science, 10(3): 954 - 957

Gupta, J. P. 1983. Soil and moisture conservation for increasing crop production in arid lands. Annual report. Jodhpur, India: CAZRI.

Gupta, M. K., and S. D, Sharma. 2009. Effect of tree plantation on soil properties, profile morphology and productivity index, II. Poplar in Yamunanagar district of Haryana. Annals of Forestry Science 17(1): 43-70.

Hairiah, K., Noordwijk, V. M., Cadisch, G. (2000). Crop yield, $\mathrm{C}$ and $\mathrm{N}$ balance of three types of cropping systems on an Ultisol in Northern Lampung. Neth. J. Agri. Sci. 48: 3-7, doi.

Ijaz, A., Adil, S.A., Hassan, S., Bakhsh, K., Bashir, M.K. and Abbas, Q. (2014). Agro-economic dimensions of intercropping in citrus farms: The case of district Toba Tek Singh, Pakistan,
Pak. J. Agri. Sci., 51(3), 763-767.

Intercropping- An approach to reduce fruit drop and improve fruit quality in guava Shailesh Kumar Singh, Madhu Sharma and Pradeep Kumar Singh.

Jensen, E.S., 1996. Grain yield, symbiotic N2 fixation and interspecific competition for inorganic $\mathrm{N}$ in pea-barley intercrops. Plant and Soil, 182: 25-38.

Korwar, G. R., G. Pratibha, V. Ravi, and D. Palanikumar. 2006. Influence of organics and Inorganics on growth, yield of aonla (Emblica officinalis) and soil quality in semi-arid tropics. Indian Journal of Agricultural Sciences 76: 457-461.

Linares, J., Scholberg, J., Boote, K., Chase, C.A., Ferguson, J.J. and McSorley, R. (2008). Use of the cover crop weed index to evaluate weed suppression by cover crops in organic citrus orchards. Hort Sci., 43:27-34.

Mahapatra, S.C., 2011. Study of grass-legume intercropping system in terms of competition indices and monetary advantage index under acid lateritic soil of India. American Journal of Experimental Agriculture, 1(1): 1-6.

Maheswarappa, H. P., M. B. Hegda, R. Dhanapal, and C. Biddappa. 1998. Mixed farming in Coconut garden: Its impact on soil physical, chemical properties, coconut nutrition, and yield. Journal of Plantation Crops 26 (2): 39143.

Maji S. and Das BC, Effect of Intercropping on Flowering and Fruiting of Guava cv. L49, Annals of Horticulture, 6(1), 2013, 76-81.

Manna, M. C. and M. V. Singh. 2001. Longterm effects of intercropping and biolitter Re- cycling on soil biological activity and fertility status of subtropical soils. Bioresource Technology 76 (2): 143-150.

Martin, M.P.L.D. and R.W. Snaydon, 1982. 
Intercropping barley and beans I. Effects of planting pattern. Experimental Agriculture, 18: 139148.

Ofori, F. and W.R. Stern, 1987. Cereallegume intercropping system. Advance in Agronomy, 41: 41-90.

Panda, M. M., Nandi, A., Bhoi, N., Senapati, N., Barik, K. C., Sahu, S. K., and Sahoo, B. C. (2003). Studies on identification of suitable intercrops for degraded land management in the North Central Plateau Agro climatic Zone of Orissa. J. Res. Orissa, Univ. Agric. Tech., 21: 62-66.

Purseglove, J.W. 1974. Tropical crops Dicotyledons. London: Longman. Prabhakar, B. S., V. Shulka and K. Srinwa (1983) Nutritional potential of vegetable intercrop-ping system. Indian J. Hort. Vol. 2 No. 3 Pp. 258268.

Reddy, M. S. and R. W. Wiley (1981) Growth and Resourceuse studies in an intercrop of Pearl millet / groundnut. Field crop Res. 4: 13-24.

Sahoo, U. K. (2016). Effect of Intercropping on Soil Health and Yield Potential of Mango in Paradise Val-ley, East Kawlchaw, Saiha District of Mizoram, NEIndia.Intl.Ecol.Envir.Sc.,42(3):227237

Sayed Roholla Mousavi1*; Hamdollah Eskandari 2 A General Overview on Intercropping and Its Advantages inSustainable Agriculture.

Singh SK and Sharma M, Evaluating significance of vermicompost and intercropping Amorph- ophallus for integrated Indian goose berry orchard management, International Journal of Agriculture Sciences, 8(39), 2016, 1809-1812.

Singh SK, Prasad J and Singh PK, Studies on economic potential of various vegetable crops as intercrops under plantation of guava (Psidium guajava L.), Bioved, 26(2), 2015, 219-222.

Singh SK, Raghuvanshi M, Singh PK and Prasad J, Performance of vegetable crops as intercrops with guava plantation, Res. Environ. Life Sci, 7(4), 2014, 259- 262.

Singh, S.K., Sharma, M. and Singh, P.K. (2016). Intercropping- An approach to reduce fruit drop and improve fruit quality in guava. J. Chem. Pharm. Sc., 9(4): 3182-3187.

Singh, Shailesh Kumar, Madhu Sharma and Singh P.K, Combined approach of intercropping and INM to improve availability of soil and leaf nutrients in fruit trees, Journal of Chemical and Pharmaceutical Sciences, 9(2), 2016, 823-829.

Srivastava, A.K., A.D. Huchche, L. Ram and S. Singh. (2007). Yield prediction in intercropped versus mono-cropped citrus orchards. Scientia Hort., 114:6770.

Swain SC, Influence of Intercropping Systems on Soil Health, Productivity and Quality of Guava (Psidium guajava L.) in Eastern India, Journal of Plant Nutrition, 2016.

Swain, S. C., and L. Patro. 2007. Horticulture-based cropping system: A strategy for sustainable development in rainfed upland. In: Environmental hazards, eds. L. Patro and S. N. Tripathy, 44-69. New Delhi: Sonali.

Tiraşçi, S., Ekinci, M., Dursun, A., and Yildirim, E. (2017). Effect of intercropping system on yield, plant growth and yield of red cabbage (Brassica oleracea L. var. rubra) and Lettuce (Lactuca sativa L.). In CONGRESS BOOK (p. 540).

Valdez, F.R. and S.C. Fransen, 1986. Cornsunflower intercropping as silage crop. Journal of Dairy Science, 69:138-142.

Vandermeer, J.H., 1992. The Ecology of 
Intercropping. Publisher: Cambridge University Press. Vishal Nath, Das, B., Rai, M., Dey, P., Kumar, S. and Kumar, M. (2003). Mango based cropping system for uplands of subhumid plateau region of Eastern India. Prog. Hort., 35: $142-45$.

Varghese, P. T., E. V. Nelliat, and T. K. Balakrishnan. 1978. Beneficial interactions of coconut-cocoa crop combination. In: Proceedings of the First Symposium on Plantation Crops, ed. Nelliat et al., 383-392, Kottyam: PLACROSYM- I.

Wahua, T.A., 1983. Nutrient uptake by intercropped maize and cow pea and concept of nutrient supplementation index (NSI). Experimental Agriculture, 19: 263-275.

Watiki, J., S. Mfukai, J.A. Banda and B.A. Keating, 1993. Radiation interception and growth of maize/cowpea intercrop as an affected by maize plant-density and cow pea cultivar. Field Crop Research, 35: 123-133.

Willey, R.W., 1990. Resource use in intercropping systems. Journal of Agriculture and Water Management, 17:215-231.

\section{How to cite this article:}

Naveen Kumar, P. 2020. Effect of Intercropping on Fruit Crops: A Review. Int.J.Curr.Microbiol.App.Sci. 9(12): 745-755. doi: https://doi.org/10.20546/ijcmas.2020.912.090 